\title{
Utjecaj tretiranja različitim koncentracijama fitohormona na ožiljavanje reznica odabranih maslina Dubrovačko neretvanske županije (Velika sitnjaka, Sitnica, Uljarica, Kalamata)
}

\author{
Impact of treating different concentrations of fitohormon \\ on to rooting cuttings of selected olive plants from \\ the Dubrovnik-Neretva county \\ (Velika sitnjaka, Sitnica, Uljarica, Kalamata) \\ Mara Marić, Marija Marinović-Peričević, Iva Mračić
}

\section{SAŽETAK}

U radu su prikazani rezultati praćenja proizvodnje reznica sorti masline Velike sitnjake, Sitnice, Uljarice i Kalamate u 2016. godini pod utjecajem tretiranja različitim koncentracijama fitohormona IBA $(2000,3000,4000$ i $5000 \mathrm{ppm})$ te su uspoređeni s rezultatima dobivenim u 2015. godine za iste sorte. Istraživanja su dio projekta "Identifikacija i gospodarenje gen-fondom maslina na području Dubrovačkoneretvanske županije" i provedena su na Zavodu za mediteranske kulture Sveučilišta u Dubrovniku.

Sorta Velika Sitnjaka je 2016. godine imala postotak ožiljavanja od 92,3\% s koncentracijom IBA od $4000 \mathrm{ppm}$. Sitnica je 2015. i 2016. godine najveće potencijale rizogeneze imala također s koncentracijom IBA od 4000 ppm, dok je Uljarica u obje godine najveće postotke ožiljavanja imala s koncentracijom IBA od 2000 ppm. Kalamata je najveće potencijale rizogeneze u obje godine pokazala $\mathrm{s}$ koncentracijom IBA od 3000 ppm s istim postotcima ožiljavanja (15\%).

Ključne riječi: autohtone sorte maslina, ožiljavanje reznicama, koncentracije hormona

\begin{abstract}
This paper presents results of monitoring the production of olives Velika sitnjaka, Sitnica, Uljarica and Kalamate in 2016, on the impact of different concentrations of phytohormone IBA $(2000,3000,4000$ and $5000 \mathrm{ppm})$ and compares them with the results obtained in 2015 for the same varieties. The research is a part of the project "Identification and management of gene-fund olives in the Dubrovnik- Neretva County" that was carried out in the Institute for Mediterranean Plants, University of Dubrovnik.
\end{abstract}


M.Marić i sur.: Ujecaj tretiranja razlicitim koncentracijama fitohormona na oživljavanje reznica odabranih maslina Dubrovačko - neretvaske županije

(Velika sitnjaka, Sitnica, Uljarica, Kalamata)

In 2016, the cultivar Velika sitnjaka had $92,3 \%$ rooting of with the applied concentration of $4000 \mathrm{ppm}$ of IBA. In 2015 and 2016, the greatest potential of rooting of the Sitnica cultivar was also established at the IBA concentration of $4000 \mathrm{ppm}$, while the Uljarica cultivar in the course of both years had the highest percentage of rooting at concentration of $2000 \mathrm{ppm}$ of IBA. The Kalamata cultivar showed the greatest potential of rhizogenesis in both years, at a concentration of $3000 \mathrm{ppm}$ of IBA, with the same rooting percentage of $15 \%$.

Key words: Autochthonous olive varieties, rooting cuttings, hormone concentrations

\section{UVOD}

Maslina (Olea europaea L.) je zimzelena subtropska voćna vrsta čiji se uzgoj u našim krajevima, kao i drugdje na Sredozemlju kroz prošlost stalno širio, a pretpostavlja se da je udomaćena na Bliskom istoku od trećeg do šestog tisućljeća prije Krista, tako da su drevni narodi istočnog Sredozemlja prvi počeli koristiti maslinu (Francolini, 1923.; Breton i sur., 2012.).

Projekt Dubrovačko-neretvanske županije i Zavoda za mediteranske kulture, Sveučilišta u Dubrovniku pod nazivom "Identifikacija i gospodarenje genfondom maslina na području Dubrovačko-neretvanske županije" je pokrenut 2015. godine s ciljem ispitivanja fizikalno-kemijskog sastava i senzorskih svojstava maslinovog ulja, formiranja kolekcijskog nasada proizvodnjom dostatne količine reznica svakog od potvrđenih autohtonih kultivara te stvaranja preduvjeta za zaštitu sortnog i zemljopisnog podrijetla maslinovog ulja autohtonih sorti Dubrovačko-neretvanske županije.

U radu donosimo dio rezultata istraživanja koji se odnose na praćenje postupka proizvodnje reznica sorti maslina Velike sitnjake, Sitnice, Uljarice i Kalamate s područja Dubrovačko-neretvanske županije tijekom 2016. godine s ciljem utvrđivanja kvalitete ukorjenjivanja reznica. Rezultati će se usporediti s rezultatima kvalitete ukorjenjivanja reznica sorti Velike sitnjake, Sitnice, Uljarice i Kalamate uzorkovanih 2015. godine i koristit će se u praktične svrhe kako bi se unaprijedila tehnika proizvodnje reznica autohtonih sorata maslina. Stoga se istraživanje nastavlja i nakon 2017. godine i formalnog završetka projekta.

Uzgoj masline na području Dubrovačko-neretvanske županije traje već stoljećima. Smatra se da je maslina jedna od prvih kultura ovog kraja. Gospodarska politika Dubrovačke Republike poticala je razvoj maslinarstva i imala bitan utjecaj na sastav sorti i asortiman što je rezultiralo bogatim izborom različitih sorti maslina i danas (Bakarić, 2005). 
M.Marić i sur.: Ujecaj tretiranja razlicitim koncentracijama fitohormona na oživljavanje reznica odabranih maslina Dubrovačko - neretvaske županije

(Velika sitnjaka, Sitnica, Uljarica, Kalamata)

Na Dubrovačkom području nalazi se preko 30 različitih sorti maslina, koje se s pravom mogu nazvati autohtone s obzirom da se drugdje na našoj obali ne mogu pronaći u tolikom broju i starosti stabla (Bakarić, 2002).

Sorta Velike Sitnjake uzgaja se najviše u središnjem dijelu Donje strane Konavala. Glavne grane su osrednje dužine, dok je deblo također osrednje veličine a krošnja okruglastog oblika. Ima krošnju veće bujnosti, u obliku kugle, zelenkaste boje. Kora na deblu je sivo-smeđe boje i lako se ljušti. Listovi su kopljastog oblika, dok su plodovi simetrični, blago izduženog oblika (Bakarić, 2005). Sitnica se uzgaja najviše u maslinicima jugoistočnog i južnog dijela Konavala, od Vitaljine, Molunta do Cavtata. Krošnja joj je bujna kao i kod Velike sitnjake, uspravnog rasta i tamnozelene boje. Glavne grane su dugačke, hrapave i tamnosive boje. Deblo je srednje veličine, kora se za razliku od Velike sitnjake slabo ljušti. Listovi su eliptična oblika, kratki i široki, a plodovi su simetrični i također eliptičnog oblika (Bakarić, 2005).

Sorta Kalamata se nalazi samo na Koločepu gdje je skroman broj stabala. Krošnje su guste u obliku kišobrana, visećih grančica. Deblo i grane prvog i drugog reda blago se uvijaju oko svoje osi u smjeru kazaljke na satu. Drvo ne podliježe lako truleži jer je tvrdo. Listovi su kopljasti, dugi i uski, dok su plodovi asimetrični i srpastog oblika (Bakarić, 2007.).

Uljarica je autohtona sorta Dubrovačkog primorja, iz Brsečina. Krošnja joj je veoma bujma, visokog rasta, tamnozelenkaste boje. Deblo je okruglasto, površina je bogata dijelovima kore koja se ljušti. Listovi su kopljastog oblika, kratki i široki, a plodovi su blago simetrični, okruglastog oblika (Bakarić, 2007.). Od 1898. godine u Hrvatskoj počinje proizvodnja sadnog materijala kada je osnovan i prvi rasadnik za proizvodnju reznica maslina u Arbanasima pokraj Zadra (Ožanić, 1955.). Sustavni rad na uvođenju metoda ukorjenjivanja zrelih i zelenih reznica maslina u Hrvatskoj započeo je sredinom šezdesetih godina prošlog stoljeća (Vlašić, 1964). Istraživanje je bilo usmjereno na ukorjenjivanje sorti Lastovke, Oblice, Levantinke i Grozdače. Temperatura supstrata bila je između 12 i $25^{\circ} \mathrm{C}$ a reznice su tretirane IBA-om u koncentraciji od $3500 \mathrm{ppm}$. Razmnožavanje maslina reznicama u svijetu je prvi primijenio Hartman (1946.) u SAD-u.

Reznice su vegetativni dijelovi biljaka koje u povoljnim i kontroliranim uvjetima iz bazalnog dijela razvijaju korijen. Najpoznatiji način u prošlosti je bio vegetativni (Jacoboni, 1989., Mladar et al., 2000.) gdje se putem ukorjenjivanja reznica s roditelja na potomstvo prenose sve osobine bez dugog juvenilnog stadija. Ova tehnika je danas u svijetu poznata kao "mist propagation" tehnologija (Metoda orošavanja). Postala je standardna metoda za razmnožavanje maslina te se sve više širi u kombinaciji $s$ modernim postrojenjima i automatskim sustavima (Petrucceli, 2012.). Metodom 
M.Marić i sur.: Ujecaj tretiranja razlicitim koncentracijama fitohormona na oživljavanje reznica odabranih maslina Dubrovačko - neretvaske županije

(Velika sitnjaka, Sitnica, Uljarica, Kalamata)

orošavanja proizvede se $71 \%$ ukupnog sadnog materijala maslina (Cimato, 2001.).

Reznice se uzimaju sa zdravih, matičnih stabala maslina maksimalne starosti od jedne godine te moraju imati minimalno tri nodija, ostavljaju se 2, 4 ili 6 listova (Cimato i Fiorino, 1980; Cimato, 1979) na gornjim nodijima. Obično imaju promjer od 0,8 do $1 \mathrm{~cm}$ i dužinu $15-20 \mathrm{~cm}$. Primjena određenih hormona na korijen, osobito kada se primjenjuje u otopini, može značajno poboljšati rezultate tako da se povećavaju ukupni postotci ukorjenjivanja, ubrzava se rast korijena, povećava broj i kvaliteta korijena. Najčešće korišten hormon je indol butilna kiselina (u daljnjem tekstu IBA) i najčešća metoda koja se koristi je tretiranje reznice 3-5 sekundi u IBA otopinu od 3000 ppm. Jedan od najvažnijih kriterija za uspješno ukorjenjivanje reznica je pouzdan supstrat za ukorjenjivanje (Izvor: www. teca.fao.org/technology/olive-propagation.com).

Najčešći supstrat za ukorjenjivanje je agroperlit granulacije $2-5 \mathrm{~mm}$ (Cimato, 1979.; Strikić, 2006.). Yahia (2015.) je istraživao utjecaj sredstava za ukorjenjivanje (perlit, smjesa treseta i perlita te smjesa pijeska i treseta) na tri sorte maslina iz Egipta (Hamed, Wateken i Maraki). Najveći postotak ukorijenjenih reznica zabilježio je u perlitu $(100 \%)$ za sorte Hamed i Wateken dok je u smjesama dobio niže postotke ukorjenjivanja ( $80 \%$ za smjesu treseta $i$ pijeska te $70 \%$ za smjesu treseta i perlita). Čimbenici koji utječu na uspjeh ukorjenjivanja maslina su: vrijeme uzimanja reznice, genetske osobine određene sorte te primjena različitih koncentracija IBA. Khajehpour i sur. (2014.) su istraživali utjecaje različitih koncentracija IBA na ožiljavanje reznica maslina postavljenih u proljeće i zimu 2012. i 2013. godine u Iranu. Reznice postavljene u proljeće su u prosjeku imale $10-15 \%$ bolje rezultate ukorjenjivanja nego reznice postavljene u zimu. Strikić (2006.) je za ukorjenjivanje sorte Istarske bjelice najbolje rezultate dobio uzimanjem reznica krajem ljeta. Brojni autori (Vlašić, 1977.; Cimato i Fiorino, 1980.; Troncoso i sur., 1981.) potvrđuju da je za zelene reznice najbolje da se uzimaju u ljetnom dok je za zrele reznice najbolje u zimskom periodu.

Denaxa i sur. (2008) su najbolji uspjeh ukorjenjivanja (96\%) za sortu Arbequina postigli s koncentracijom IBA od 2000 ppm dok je uspjeh od 100\% kod sorte Pendolino zabilježio Cimato (1979) tretirajući reznice s IBA u koncentraciji od $4000 \mathrm{ppm}$. Najveći postotak ukorjenjivanja reznica za sorte maslina iz Egipta je postignut $\mathrm{s}$ koncentracijom IBA od $3000 \mathrm{ppm}$ dok je koncentracija IBA od $4000 \mathrm{ppm}$ dala najbolje rezultate što se tiče duljine korijena reznica (Yahia, 2015.). Ispitivani su utjecaji IBA na ožiljavanje reznica maslina u kombinacijama s drugim sredstvima. Kombinirani su urea-fosfat (UP) i paklobutrazol (PB) u kombinaciji sa IBA s ciljem poboljšanja ukorjenjivanja reznica maslina.

60 
M.Marić i sur.: Ujecaj tretiranja razlicitim koncentracijama fitohormona na oživljavanje reznica odabranih maslina Dubrovačko - neretvaske županije

(Velika sitnjaka, Sitnica, Uljarica, Kalamata)

Dokazano je da samo UP i PB nisu potaknuli ukorjenjivanje reznica maslina ali u kombinaciji sa IBA je poboljšano ukorjenjivanje (Z. Wisman; S. Lavee, 1995.). Moshtaghi i sur. (2011.) su tretirali reznice maslina sorti Roghani i Tokhmkabki u Iranu s IBA u koncentraciji od $4000 \mathrm{ppm}$, te vodikovim peroksidom 3,5\% $\mathrm{H}_{2} \mathrm{O}_{2}$ i kombinacijom IBA i $\mathrm{H}_{2} \mathrm{O}_{2}$. Reznice tretirane samo $\mathrm{s}_{2} \mathrm{O}_{2}$ nisu pokazale dobre rezultate ožiljavanja. Kombinacija tretiranja IBA i $\mathrm{H}_{2} \mathrm{O}_{2}$ nije pokazala nikakve značajnije rezultate u usporedbi s reznicama koje su tretirane samo s IBA. U prostoru za ukorjenjivanje relativna vlažnost zraka mora biti između 95-98\% dok se za temperaturu supstrata preporuča da bude između 18-24 ${ }^{\circ} \mathrm{C}$ (Hartmann, 1946.; Strikić, 2001.). Različiti autori navode i različite temperature supstrata tako da Cimato (1979.) navodi temperaturu supstrata od $26^{\circ} \mathrm{C}$ pri kojoj postiže dobar uspjeh ukorjenjivanja. Cimato (1980.) i Strikić (2006.) kao optimalno vrijeme trajanja procesa ukorjenjivanja navode 90 dana.

\section{MATERIJAL I METODE}

$\mathrm{Za}$ ožiljavanje maslina uzorkovane su zrele reznice s odabranih i označenih stabala različitih sorti u privatnim maslinicima gdje se provode sve agrotehničke mjere na području Dubrovačko-neretvanske županije uključujući Konavle (Komaji, Vitaljina), Dubrovačko primorje (Brsečine) i Elafiti (Koločep). Reznice su uzorkovane u razdoblju od 20.09. do 06.10.2016. godine.

Na području Konavala (Komaji i Vitaljina) uzorkovane su reznice Velike sitnjake i Sitnice. Matično stablo Velike Sitnjake u Komajima sadrži više starih odrveljenjenih izboja, što je za iduće pokuse planirano orezati dok je matično stablo Sitnice u Vitaljini staro s previsokim izbojima koje je planirano pomladiti. U Dubrovačkom primorju na području Brsečina uzorkovana je sorta Uljarica. Matično stablo je staro pomlađeno stablo koje se planirano oblikovati. S otoka Koločepa su uzete reznice sorte Kalamata sa matičnog stable čije deblo je visoko i staro i koje se također planira pomladiti iduće godine. Uzorkovano je ukupno 611 reznica ispitivanih sorti maslina. Proces ukorjenjivanja reznica je trajao ukupno 120 dana. Pratila se sposobnost ožiljavanja reznica maslina što je obuhvatilo određivanje postotka ožiljavanja pri određenoj koncentraciji hormona u određenim uvjetima (slika 2.).

Na grafikonima 1. i 2. prikazane su prosječne dnevne temperature za drugu polovicu rujna te prvu polovici listopada 2016. godine. Analiza temperaturnih anomalija za rujan 2016. godine pokazuje da su srednje mjesečne temperature zraka bile iznad višegodišnjeg prosjeka dok analiza temperaturnih anomalija za listopad 2016. godine pokazuju da su srednje mjesečne temperature zraka bile većinom ispod višegodišnjeg prosjeka (Izvor: www.meteoinfo.hr). 
M.Marić i sur.: Ujecaj tretiranja razlicitim koncentracijama fitohormona na oživljavanje reznica odabranih maslina Dubrovačko - neretvaske županije

(Velika sitnjaka, Sitnica, Uljarica, Kalamata)

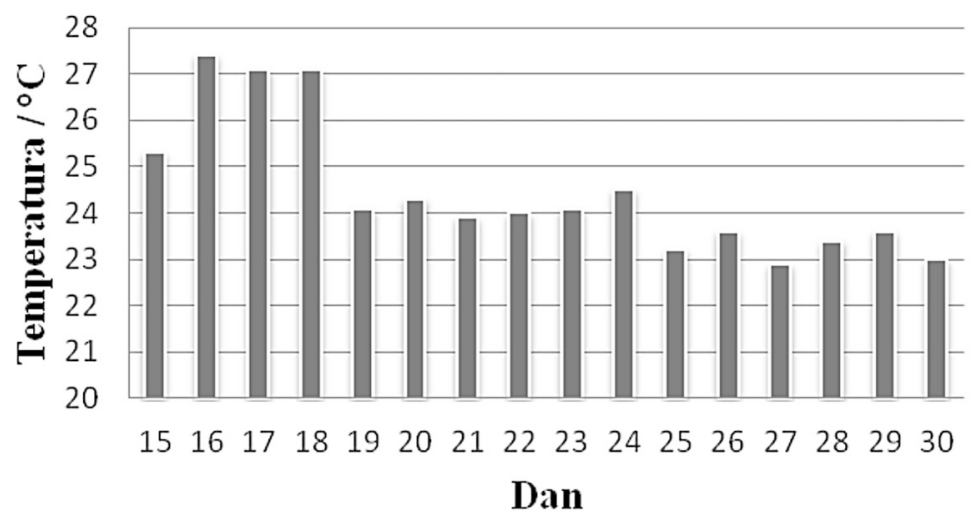

Grafikon 1. Maksimalne temperature zraka $\left({ }^{\circ} \mathrm{C}\right)$ za Dubrovačko područje u drugoj polovici mjeseca rujna 2016. godine

Chart 1. Maximum air temperature $\left({ }^{\circ} \mathrm{C}\right)$ for Dubrovnik area during the second half of September 2016

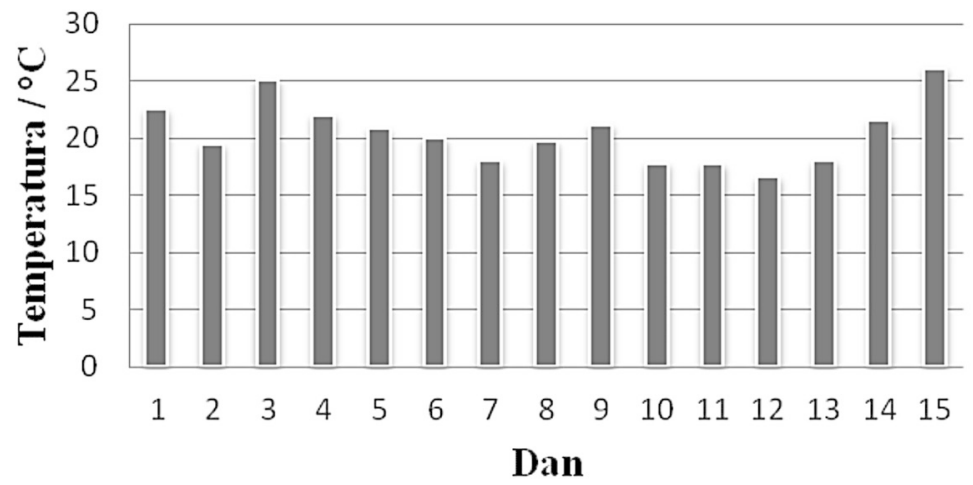

Grafikon 2. Maksimalne temperature zraka $\left({ }^{\circ} \mathrm{C}\right)$ za Dubrovačko područje u prvoj polovici mjeseca listopada 2016. godine

Chart 2. Maximum air temperature $\left({ }^{\circ} \mathrm{C}\right)$ for Dubrovnik area during the first half of October 2016 
M.Marić i sur.: Ujecaj tretiranja razlicitim koncentracijama fitohormona na oživljavanje reznica odabranih maslina Dubrovačko - neretvaske županije

(Velika sitnjaka, Sitnica, Uljarica, Kalamata)

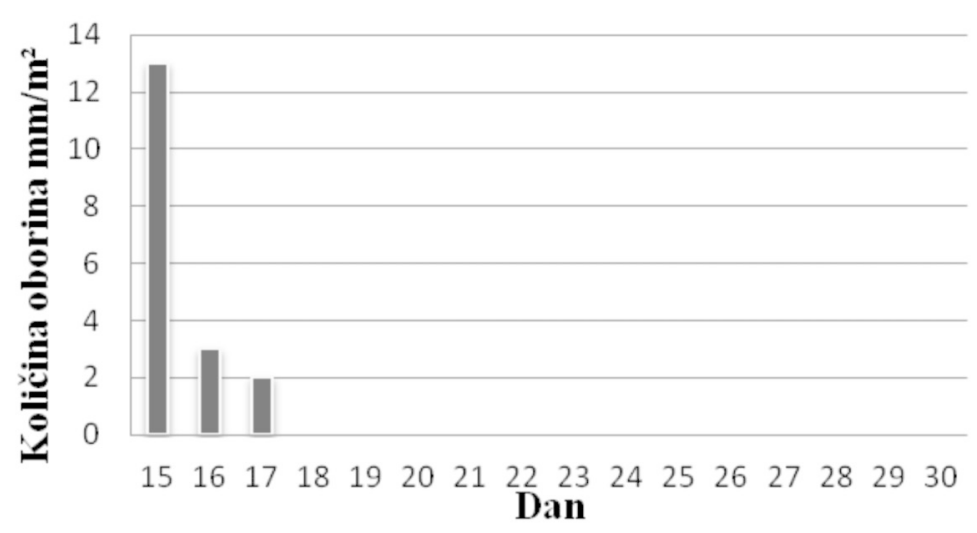

Grafikon 3. Količine oborina $\left(\mathrm{mm} / \mathrm{m}^{2}\right)$ za Dubrovačko područje u drugoj polovici mjeseca rujna 2016. godine

Chart 3. Amount of precipitation $\left(\mathrm{mm} / \mathrm{m}^{2}\right)$ for Dubrovnik area during the second half of September 2016

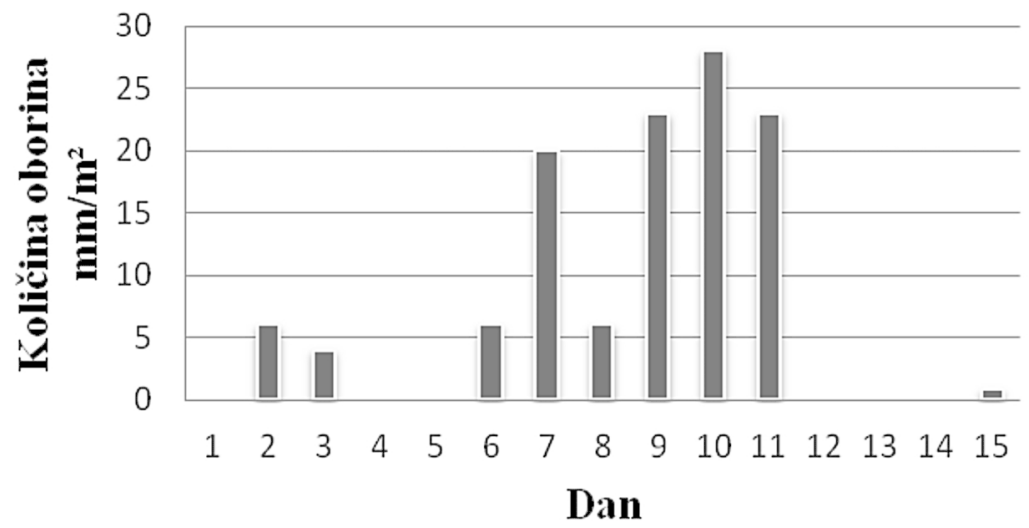

Grafikon 4. Količine oborina $\left(\mathrm{mm} / \mathrm{m}^{2}\right)$ za Dubrovačko u prvoj polovici mjeseca listopada 2016. godine

Chart 4. Amount of precipitation $\left(\mathrm{mm} / \mathrm{m}^{2}\right)$ for Dubrovnik area during the first half of October 2016 
M.Marić i sur.: Ujecaj tretiranja razlicitim koncentracijama fitohormona na oživljavanje reznica odabranih maslina Dubrovačko - neretvaske županije

(Velika sitnjaka, Sitnica, Uljarica, Kalamata)

Na grafikonima 3. i 4. prikazane su količine oborina za drugu polovicu rujna te prvu polovicu listopada 2016. godine. Analiza količina oborina za rujan 2016. godine pokazuje da su količine oborina bile ispod prosjeka dok su količine oborina za listopad 2016. bile iznad prosjeka.

Eksperimentalni dio ovog istraživanja odrađen je u množarniku Zavoda za mediteranske kulture u kojem je smješten stol dužine $6 \mathrm{~m}$, širine $1 \mathrm{~m}$. Na dnu stola su instalirane cijevi u razmaku od $10 \mathrm{~cm}$, kojima struji topla voda. Stol je prekriven PVC prozirnom folijom kako bi se očuvali određeni klimatski uvjeti temperature i vlage zraka. Sustav za orošavanje je povezan sa stolom, sastavljen od cijevi na kojima su instalirani mikrorasprščivači.

Dinamika orošavanja je bila dnevno svakih trideset minuta u trajanju od 5 sekundi. Temperatura i vlaga zraka kao i temperatura supstrata kontrolirani su dnevno mjernim uređajem Testo. Temperatura supstrata je održavana između 18 i $23{ }^{\circ} \mathrm{C}$ i prostora 19 do $25{ }^{\circ} \mathrm{C}$, a relativna vlažnost zraka je u prosjeku bila $89 \%$.

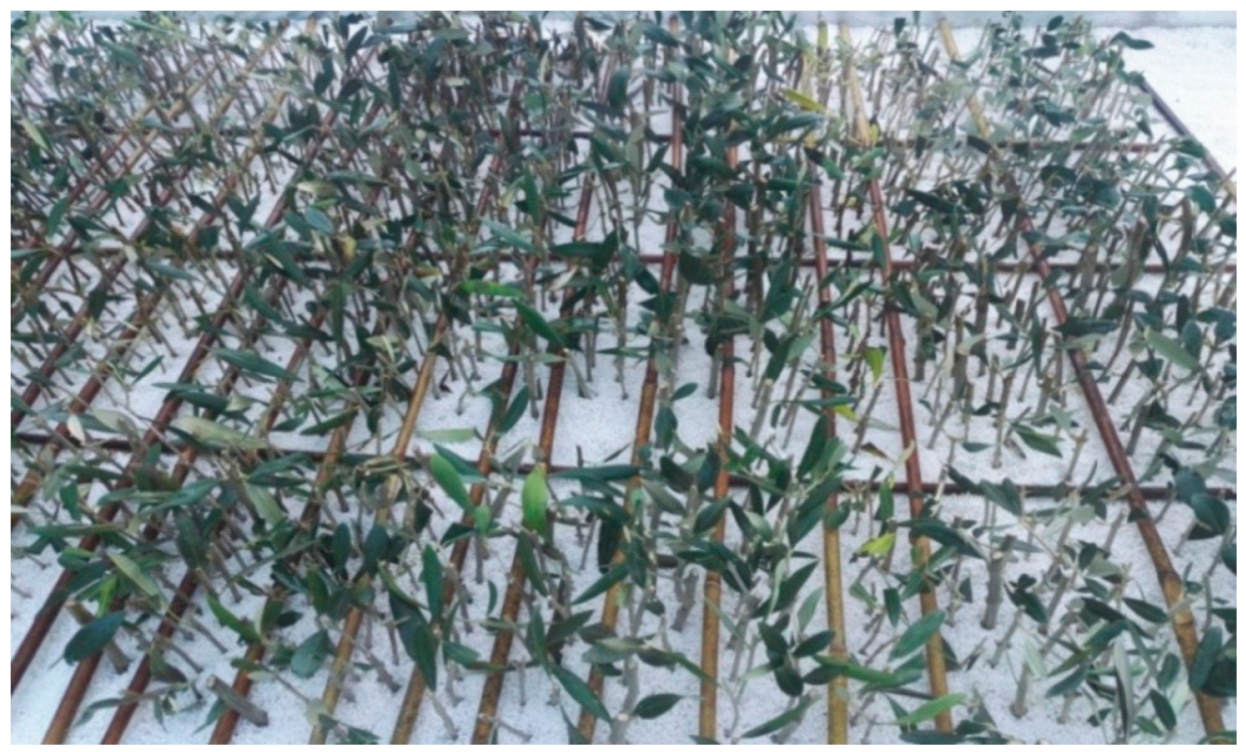

Slika 1. Reznice različitih sorti postavljene u množarniku Zavoda za mediteranske kulture Sveučilišta u Dubrovniku

Picture 1. Cuttings of different olive varieties located in hothouse of the Institute for Mediterranean Plants, University of Dubrovnik 
M.Marić i sur.: Ujecaj tretiranja razlicitim koncentracijama fitohormona na oživljavanje reznica odabranih maslina Dubrovačko - neretvaske županije

(Velika sitnjaka, Sitnica, Uljarica, Kalamata)

Kao supstrat za ukorjenjivanje korišten je agroperlit, postavljen u stolu od $20 \mathrm{~cm}$ granulacije $3-5 \mathrm{~mm}$. S odabranih stabala uzimani su prošlogodišnji izboji duljine 50-70 cm, promjera 6-8 mm. Nakon toga su vezani u snopove, koji su označeni etiketom s imenom sorte $i$ omotani vlažnom tkaninom radi očuvanja vlage. Reznice su tretirane fungicidima aktivne tvari propamokarba radi preventivne zaštite od gljivičnih bolesti koje se pojavljuju tijekom procesa ukorjenjivanja masline.

Reznice su istog dana postavljene $u$ supstrat $u$ razmaku od $5 \times 5 \mathrm{~cm}$, tretirane s četiri različite koncentracije fitohormona od 2000, 3000, 4000 i 5000 ppm-a, koje su pripremljene u obliku alkoholne otopine (Slika 1.). Tretirane su sve istraživačke sorte maslina sa sve četiri koncentracije hormona.

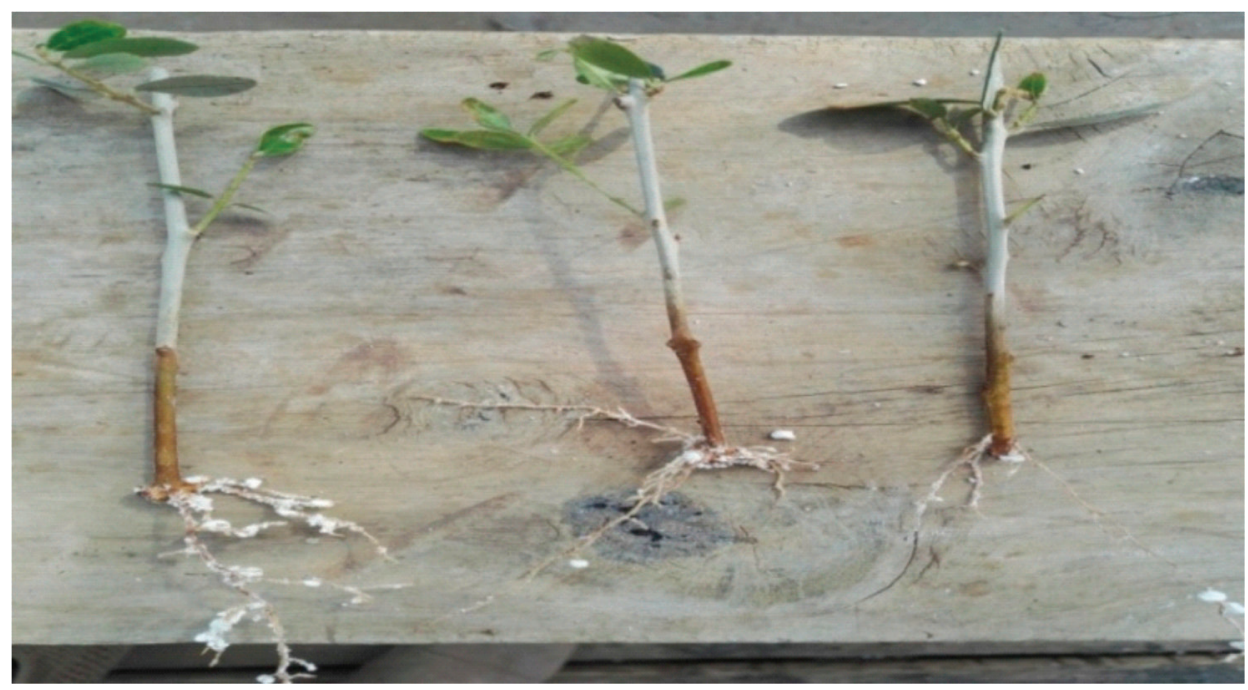

Slika 2. Prikaz ožiljenih reznica različitih sorti maslina

Picture 2. Display of rooted cuttings of different olive varieties

\section{REZULTATI I RASPRAVA}

U tablici 1. prikazani su rezultati (od najboljih prema najnižem) postotka uspješnosti ukorjenjivanja po sortama $\mathrm{s}$ četiri različite koncentracije IBA hormona (2000, 3000, 4000, $5000 \mathrm{ppm})$.

Iz dobivenih rezultata je vidljivo da je Velika sitnjaka od istraživanih sorti pokazala najveći potencijal u procesu rizogeneze pri svim koncentracijama IBA. Najbolji postotak ukorjenjivanja je imala pri koncentraciji IBA od 4000 ppm 
M.Marić i sur.: Ujecaj tretiranja razlicitim koncentracijama fitohormona na oživljavanje reznica odabranih maslina Dubrovačko - neretvaske županije

(Velika sitnjaka, Sitnica, Uljarica, Kalamata)

$(92,3 \%)$, dok je najniži postotak imala pri koncentraciji od 5000 ppm (75\%). Sorta Sitnica je najbolji uspjeh ukorjenjivanja pokazala pri koncentraciji od 4000 ppm (25,7\%), dok je najniži također pri koncentraciji od 5000 ppm $(7,5 \%)$ kao i sorta Kalamata koja je najveći potencijal rizogeneze pokazala pri 4000 ppm $(15,4 \%)$ a $0,00 \%$ ožiljavanja je pokazala s koncentracijom IBA od 5000 ppm. Zanimljivo je da su iste koncentracije IBA za različite sorte u Egiptu i Italiji također potvrđene kao najbolji rezultati. Najveći postotak ukorjenjivanja $(100 \%)$ iznosili su za koncentracije 4000 i 5000 ppm IBA u supstratu perlitu za sorte Wateken i Hamedovom (Yahia, 2015) dok je Cimato (1979) uspjeh ukorjenjivanja od $100 \%$ postigao tretirajući sortu Pendolino s IBA koncentracijom od $4000 \mathrm{ppm}$.

Tablica 1. Broj reznica za ukorjenjivanje i postotak njegove uspješnosti za sorte maslina

Table 1. The number of rootstock cuttings and the percentage of enrooting for olive varieties

\begin{tabular}{|c|c|c|c|c|}
\hline Sorta & $\begin{array}{l}\text { Koncentracija } \\
\text { IBA (ppm) }\end{array}$ & $\begin{array}{l}\text { Broj } \\
\text { reznica }\end{array}$ & $\begin{array}{c}\text { Broj } \\
\text { ukorjenjenih }\end{array}$ & \% uspješnosti \\
\hline \multirow{4}{*}{ Velika sitnjaka } & 2000 & 13 & 10 & 76,9 \\
\hline & 3000 & 13 & 11 & 84,6 \\
\hline & 4000 & 13 & 12 & 92,3 \\
\hline & 5000 & 12 & 9 & 75 \\
\hline Ukupno & & 51 & 42 & 82,4 \\
\hline \multirow{4}{*}{ Sitnica } & 2000 & 66 & 7 & 10,6 \\
\hline & 3000 & 66 & 8 & 12,1 \\
\hline & 4000 & 66 & 17 & 25,7 \\
\hline & 5000 & 67 & 5 & 7,5 \\
\hline Ukupno & & 265 & 37 & 13,9 \\
\hline \multirow{4}{*}{ Uljarica } & 2000 & 35 & 3 & 8,6 \\
\hline & 3000 & 35 & 1 & 2,9 \\
\hline & 4000 & 35 & 1 & 2,9 \\
\hline & 5000 & 34 & 0 & 0,0 \\
\hline Ukupno & & 139 & 5 & 3,7 \\
\hline \multirow{4}{*}{ Kalamata } & 2000 & 39 & 3 & 7,7 \\
\hline & 3000 & 39 & 6 & 15,4 \\
\hline & 4000 & 39 & 5 & 12,8 \\
\hline & 5000 & 39 & 0 & 0,0 \\
\hline Ukupno & & 156 & 14 & 9,0 \\
\hline
\end{tabular}


M.Marić i sur.: Ujecaj tretiranja razlicitim koncentracijama fitohormona na oživljavanje reznica odabranih maslina Dubrovačko - neretvaske županije

(Velika sitnjaka, Sitnica, Uljarica, Kalamata)

U usporedbi s istraživanjima provedenim 2015. godine na sortama Velike Sitnjake, Sitnice, Uljarice i Kalamate (Barnjak Vukas i sur., 2015) uzorkovane s istih stabala na istim lokacijama kao i 2016. godine pokazale su slične rezultate što se tiče izbora koncentracije IBA hormona ali su postotci ožiljavanja te godine kod sorti Sitnice i Uljarice manji u usporedbi s prošlom godinom, dok su kod Velike Sitnjake puno veći a kod Kalamate gotovo identični.

Sitnica je 2015. godine imala 65\% ukorijenjenih reznica pri koncentraciji IBA od $4000 \mathrm{ppm}$, dok je ove godine imala tek $25,7 \%$. Uljarica je 2015 . godine najbolji rezultat ukorjenjivanja od $23 \%$ imala pri koncentraciji IBA od 2000 ppm, dok je 2016. godine s istom koncentracijom hormona dobiven rezultat od $8,6 \%$. Kalamata je u obje godine najbolji rezultat imala pri koncentraciji od $3000 \mathrm{ppm}$ s gotovo istim postotcima ukorjenjivanja (15,4\% i 16\%).

Slabiji rezultati uspješnosti ukorjenjivanja reznica su vjerojatno posljedica lošijih klimatskih uvjeta i različitog vremena uzorkovanja reznica. Reznice ovih sorti maslina su ove godine uzorkovane u mjesecu listopadu kad je količina padalina bila iznad prosjeka, te je nakon toga prevladalo izrazito sušno razdoblje, dok su 2015. godine reznice uzorkovane u rujnu kada su temperature zraka bile više ali količina oborina u skladu s prosjekom što je bolje pogodovalo ožiljavanju reznica (Izvor: www.meteo-info.hr).

Proces ukorjenjivanja reznica 2015. godine je trajao 90 dana, dok je 2016. godine trajao 120 dana, što dokazuje da su za određene sorte poput Sitnice i Uljarice bolji rezultati ožiljavanja kad proces ukorjenjivanja kraće traje kao što i neki autori (Cimato,1980.; Strikić, 2006.) navode da je optimalno vrijeme procesa ukorjenjivanja 90 dana.

Dobiveni rezultati 2016. godine za uspješnost ukorjenjivanja sorte Velike sitnjake su drugačiji nego rezultati dobiveni 2015. godine. Najveću uspješnost ukorjenjivanja 2015. godine je postignuta koncentracijom IBA s 2000 ppm (20\%). Tretiranjem koncentracijom IBA od $2000 \mathrm{ppm}$ u 2016. godini postigao se uspjeh ukorjenjivanja od $76,9 \%$ što nije najveći rezultat. Najveću uspješnost ukorjenjivanja $(92,3 \%)$ je pokazala koncentracija IBA od 4000 ppm, dok su s istom konecntracijom u 2015. godini dobiveni rezultati od $0,00 \%$.

Sorte su 2015. i 2016. godine također pokazale veoma loše uspjehe ukorjenjivanja pri koncentraciji IBA od 5000 ppm, pa se može zaključiti da ispitivanim sortama $\mathrm{s}$ Dubrovačkog područja ne pogoduju previsoke koncentrirane hormonske otopine kao ni preblage, slabe, već im najviše pogoduju srednje, umjereno koncentrirane hormonske otopine. 
M.Marić i sur.: Ujecaj tretiranja razlicitim koncentracijama fitohormona na oživljavanje reznica odabranih maslina Dubrovačko - neretvaske županije

(Velika sitnjaka, Sitnica, Uljarica, Kalamata)

ZAKLJUČAK

Istraživanja utjecaja koncentracija IBA za iste sorte provedene u dvije različite godine pokazale su slične rezultate što se tiče koncentracija IBA ali su postotci ožiljavanja 2016. kod sorti Sitnice i Uljarice manji u usporedbi s prošlom godinom, dok su kod Velike Sitnjake puno veći a kod Kalamate gotovo identični. Na rezultate su utjecali klimatski uvjeti, vrijeme uzorkovanja reznica te duljina trajanja procesa ukorjenjivanja.

Loši uspjesi ukorjenjivanja kod svih ispitivanih sorti pokazali su se pri koncentraciji IBA od 5000 ppm dok se ni kod koncentracije IBA od 2000 ppm nisu postigli veliki uspjesi ukorjenjivanja reznica. Ispitivanim sortama najviše pogoduju srednje, umjerene koncentrirane hormonske otopine.

Istraživanja vezana za utjecaj koncentracija fitohormona na navedene sorte će se nastaviti i u 2018. godini. U tu svrhu planirano je provesti sve potrebne agrotehničke mjere na matičnim stablima što bi trebalo pridonijeti kvalitetnijem rezultatu. Vrijeme uzorkovanja reznica za idući pokus planirat će se za mjesec rujan te će proces ukorjenjivanja trajati do maksimalno tri mjeseca.

\section{LITERATURA}

BAKARIĆ, P. (2002.): Sorte maslina Dubrovačkog primorja. Alfa 2. Dubrovnik. 92-97.

BAKARIĆ, P. (2005.): Stare konavoske sorte masline. Alfa 2. Dubrovnik. 2643.

BAKARIĆ, P. (2007.): Autohtone sorte maslina Elafita. Alfa 2. Dubrovnik. 6065.

BARNJAK VUKAS, M.; MARIĆ, M.; MARINOVIĆ-PERIČEVIĆ, M. (2015.): Utjecaj koncentraciuje IBA na kvalitetu ožiljavanja reznica odabranih autohtonih sorata maslina Dubrovačkog kraja. Zbornik Sveučilišta u Dubrovniku 3. 1-11.

BRETON, C.M., WARNOCK, P., BERVILLE A.J. (2012.): Origin and History of the Olive, Olive Germplasm - The Olive Cultivation, Table Olive and Olive Oil Industry in Italy, Muzzalupo, I. (ed.), Dostupno na: http://www.intechopen.com 03. ožujka 2017.

CIMATO, A. (1979.): La moltoplicazione dell' olivo in nebulizzazione: Attitudine alla radicazione di 24 cultivar di olivo(Olea europeae L.) coltivate nell' meridionale. Scienza e Tecnica Agraria. 5-6. 
M.Marić i sur.: Ujecaj tretiranja razlicitim koncentracijama fitohormona na oživljavanje reznica odabranih maslina Dubrovačko - neretvaske županije

(Velika sitnjaka, Sitnica, Uljarica, Kalamata)

CIMATO, A. (2001.): Struttura ed orientamenti produttivi del vivaismo olivicolo. Multiplication et cerfification des plants d Olivier. Actes du Seminaire International: 51-62.

CIMATO, A.; FIORINO,P. (1980.): La moltiplicazione dell' olivo con la tecnica dell nebulizzazione.L'informatore agrario 12177-12268.

DENAXA, N. K.VEMMOS, N.; ROUSSOS, P.; KOSTELENOS, G. (2008.): The Effect of IBA, NAA and Carbohydrates on Rooting Capacity of Leaf Cuttings in Three Olive Cultivars (Olea europea L.), Journal of Horticultural Science 66 (3):301-309

FRANCOLINI, F. (1923.): Olivicoltura. Torino, Italy: UTET

HARTMAN, H. T. (1946.): The use of root-promoting substance in the propagation of olive by soft-wood cuttings. Proc. Am. Soc. Hort. Sci.48. 303-308.

JACOBONI, N. (1989.): Propagation. Oliova 25.

KHAJEHPOUR, G.; JAMÍEIZADEH, V.; KHAJEHPOUR, N. (2014.): Effect of Different Concentrations of IBA (Indulebutyric Acid) Hormone and Cutting Season on the Rooting of the Cuttings of Olive (Olea Europaea Var Manzanilla). Int. J. Adv. Biol. Biom. Res. 2. 2920-2924

YAHIA, I. M. (2015.): Evaluation the effect of rooting media and hormonal concentrations (IBA) in three olive cultivars growing in SiwaOesis Egypt. International Journal of Agricultural Sciences. 500-503.

MLADAR, N.; STRIKIĆ, F., ROŠIN, J. (2000.): Obnova starih maslinika. Zbornik sažetaka Znanstvenog skupa "Unapređenje poljoprivrede i šumarstva na kršu”, Institut za jadranske kulture. Split. 38-49.

MOSHTAGHI, E.; SHAHSAVAR, A.R. (2011.): The Effects of IBA and H2O2 on Rooting of 2 Olive Cultivars. Journal of Chemical Health Risks. 35-38.

OŽANIĆ, S. (1955.): Poljoprivreda Dalmacije u prošlosti. Izdanje društva agronoma NRH podružnica Split, Split.

PETRUCCELli, R.; MICHELI, M.; PROIETTI, P.; GANINO, P. (2012.): Moltiplicazione dell'olivo e vivaismo olivicolo in Italia. Italus Hortus 19. 322.

STRIKIĆ, F. (2001.): Utjecaj koncentracije IBA-e i vremena uzimanja reznica sorata maslina na rizogenezu- Magistarski rad-Zagreb 2001. 77. 
M.Marić i sur.: Ujecaj tretiranja razlicitim koncentracijama fitohormona na oživljavanje reznica odabranih maslina Dubrovačko - neretvaske županije

(Velika sitnjaka, Sitnica, Uljarica, Kalamata)

STRIKIĆ, F.; ČMELIK, Z.; PECINA, M.; POLJAK, M. (2006.): Fiziološka faza matičnog stabla kao čimbenik rizogeneze masline. Pomologia Croatica. 12(6). 127-144.

TRONCOSO, A. ;BARTOLINI, G.; MAZUELOS, C. ;NICOLAS, A. (1981.): Radicazioe di tale di olivo cv "Frangivento" prevenienti da diversi ambienti.2. Relazione con la stato nutrizionale dell talea.Riv.ortoflorofrutticoltura Ital. 3-65.

VLAŠIĆ, A. (1964.): Ukorjenjivanje reznica metodom mist-utjecaj supstrata. Agronomski glasnik 6. 395-396.

VLAŠIĆ, A. (1977.): Razmnožavanje masline ukorjenjivanjem reznica. Jug. Voćarstvo. 39-40. Čačak.

WISMAN, Z.; LAVEE, S. (1995.): Enhancement of IBA stimulatory effect on rooting of olive cultivar stem cuttings. Scientia Horticulturae. 189-198.

Internet adrese:

http://www.meteo-info.hr (06. 3. 2017.)

http:// www. teca.fao.org/technology/olive-propagation.com

\section{Adresa autora - Author's address:}

Doc.dr.sc. Mara Marić,dipl.ing.agr.

e-mail: mara.maric@unidu.hr

Marija Marinović-Peričević,dipl.ing.agr.

e-mail: marija.marinovic-pericevic@unidu.hr

Iva Mračić, mag.ing.preh.ing.

e-mail: iva.mracic@unidu.hr

Zavod za mediteranske kulture, Sveučilište u Dubrovniku

Marka Marojice 4, Dubrovnik 